\title{
Effect of Leadership Style on Working Culture and Employees Motivation
}

\author{
Maryam Khaliq ${ }^{1}$, Amna Usman ${ }^{2}$, Aqeel Ahmed ${ }^{3}$
}

\section{Abstract}

Based on a recent call for further research. This study is expected to quantify the impact of rational-legal, traditional, charismatic leadership style on employee's motivation and working culture. Using the survey method data was collected from 215 employ ees, and 15 leaders. The underpinning objective of the current study is to test the underpinning theory. The response rate was observed by 55\% using the simple random sampling technique. The findings of current study indicate a positive and significant role of leaders on the working culture and employee's motivation. Results further show that the study's five variables had played a significant role, and the results have some practical implications for Employees, Leaders, HRM departments, and organizations.

Keywords: Leadership, working culture, employee's motivation, HRM, organizations.

Leadership style has a significant influence on employee's motivation and enhances the quality of working culture. There is a paradigm in leadership styles from traditional rigid leaders to leaders of 21 century who are very flexible and friendly towards their woks force. Now organizational goals have gone far complicated, so organizations need a motivated workforce with multiple creative minds, and people also love to work in teams rather than individuals. They feel more motivated and satisfied in the workplace when they have appropriate direction to achieve their tasks, and this is all possible with the help of suitable leadership styles. Leadership style builds a healthy working culture of an organization by making it more humane, flexible, and friendly with the loyalty of satisfied employees (Zhao, \& Begley, 2015).

The organization takes different steps to boost an excellent work culture because quality work culture is critical to reinforce employee performance. Organizational culture renders itself to provide strength to the organization and simultaneously act as a hurdle in development like Japanese cultures are ideal for other organizations because both the employees and the organization treat each other as a family. Leaders of the $21^{\text {st }}$ century must pay attention to their human capital to keep them happy, satisfied, and motivated to achieve their long-term goals by winning employees' hearts.

Many researchers have investigated different leadership styles effect on employee satisfaction and performance. Still, this research work explores the impact of leadership styles on an organization's work culture to which employees' motivation is linked. This study observes how appropriate leadership styles encourage motivation and working culture at the same time

Many researchers highlighted the problems arising while selecting an effective suitable leader for a specific organizational culture. Organizations must face the music if they choose an ineffective and incapable leader who lacks the caliber to tackle all the issues inside the organization. So, to identify a leader who will make work culture happy and elastic is crucial. So often, leaders think about if their rigidity is harming an organization's culture and resulting in employee turnover or their extra leniency is detrimental to the discipline of the organization. This study would try to answer this dilemma for the success of an organization.

1: what is the significance of identifying different leadership styles that may appear in the workplace?

2: how does culture influence different leadership styles when the link to employee's motivation?

This study's main objective is to find out the effect of different leadership styles on employee's motivation and working culture and how specific working culture is linked with workforce motivation when a leadership style influences both culture and motivation.

- To know the significance of leadership styles on workforce motivation.

- To evaluate the relationship between working culture and employee motivation.

- To know the importance of leadership styles on working culture. Literature Review

The word leadership first appeared in the oxford dictionary as late as 1800 . There are extensive research papers and literature on this concept providing more than 350 definitions of this terminology. There are many interpretations of leadership style, but each one remained incomplete and is unable to cope with the rapidly changing dynamic organizations and its components. However, all the definitions shared a common point: leadership style is one of the most significant factors to lead an organization towards the path of success or may turn towards its failure (Al Rahbi, et al, 2017). Literature suggests that leadership is a social activity that influences employees' voluntary participation to accomplish organizational goals. A leader could be defined as a frontman, spokesperson, or influencer who exercises power and gives others direction to execute the organization's specified objectives (Nanjundeswaraswamy, \& Swamy, 2014).

\footnotetext{
${ }^{123}$ UCP Business School, Faculty of Management Studies, UCP, Pakistan. Corresponding author Email: aqeel.a@ucp.edu.pk
} 
Another significant aspect of leading is motivating employees. Academics often talk about the value of an enterprise's human capital, by which they mean the skills and motivations of its employees. Rose Marie Bravo recognized the importance of human capital when she took on Burberry's top management position. In her tenure, she engineered a remarkable turnaround, leading to Burberry's complete transformation into a high-end fashion brand. Today, it is the need for an organization to have an effective leader capable enough to cope with the challenges and intrications of the rapidly changing global environment. To ensure an organization's survival in a complex, dynamic, and challenging environment. A leader must keep on learning and be flexible enough to adapt him or herself according to the situation. He should be highly responsible for the task of subordinates (Ali, Norlina et al, 2015). From the literature, the traits of many influencing leaders in history could be studied. Some examples of strong leaders include Martin Luther King, Steve Jobs, Winston Churchill, Napoleon, and Imran khan.

Leadership styles used in the study

\section{Traditional leadership style}

There are many theories on a traditional leadership style that investigates the desired characteristics of a leader like great man theory, trait theory approach, Ohio, and Michigan state studies in 1960, which focus on leaders' behaviors and the last one on contingency approach; least preferred co-worker theory. Traditional leadership style focuses. By going through the literature, the study focused on the Trait theory approach for traditional leadership style. It is one of the earliest theories on leadership and is often tied to great man theory proposed by Thomas Carlyle. It states that leaders are 'born not made' (Leadership is more likely to be in-built rather than learned from experience. Carlyle concluded that 'outstanding leaders influence history, and the ability to lead was something that you earned at birth and not something that could be created.

Some early work on leadership mainly focused on the relationship between personality and leadership. Later (Bono, \& Judge, 2004) published their work between 1990 and 2004, stating that $12 \%$ of the research on leadership included the keywords 'personality and leadership'. So, it could be suggested that leadership style is triggered by personality. Concurrently there are many research studies to differentiate between leaders and non-leaders and analyze accurate and relevant leadership trait tests. However, researchers discovered that only a few traits create a boundary between leaders and followers like Height, intelligence, extraversion, adjustment, dominance, commitment, and selfconfidence.

In1989, John W. Gardner published research work a considerable number of leaders and deduced that some attributes appear to make a leader successful in any situation (John Fleener 2006). There is some limitation of trait theory as recent research suggested that innate and heritable leadership characteristic invokes at about $30 \%$. Remaining $70 \%$ comes from situational factors. So now this theory faces the criticism of being called as dustbowl empiricism. For instance, in the U.K., to be elected in U.K. civil service, a candidate must fill a questionnaire on personality named '16PF5' personality measure to assess the individual leadership style and behavior. This questionnaire is multiple-choice based and contains 183 questions. The candidate's resulting profile is discussed with a candidate through an interview and analyzed by an occupational psychologist.

\section{Bureaucracy theory}

Bureaucracy's theory of Max Weber supports the study conducted and provides evidence in this regard. (Weber, 1968, p.215 ff.). this theory revolves around the idea of authority. Max Weber has contributed a lot in leadership styles. Each MAX WEBER leadership authority correlates with a brand of operative leadership in contemporary society. Traditional leadership style by Weber: in 1947, Max weber was the one to describe the conventional leadership style along with charismatic and bureaucratic. In the traditional leadership style, power is bestowed on the leader just to keep the traditions of the past. Without any struggle and mark, a leader can come into possession of authority, i.e., kings, dictators, and some business leaders (Weber, 1974). Some of the features for traditional authority are;

$\checkmark$ Leaders are the sole person to exercise control and power in the organization because of his position.

$\checkmark$ Employees follow their leader due to the attachment with their traditions and personal loyalty to a position.

$\checkmark$ Employees are promoted based on nepotism, racism, and favoritism.

$\checkmark$ Bureaucracy and red-tapism are high in the organization.

\section{Rational-legal leadership style}

This type of authority is clearly and implicitly embedded in-laws. Power must not be exercised on employees merely based on leader position and capacity but because of the legitimacy and competence of the procedures and laws incorporated by that individual. Contemporary societies rely on this sort of leadership style.

\section{Charismatic leadership style}

Charismatic leadership refers to an individual who owns specific traits that make him an extraordinary and astonishing leader. That leader possesses the superiority of charisma of his personality and can make people his followers blindly. People have enormous trust in him and almost have unbreakable faith. (Max Weber, 1947)

\section{Working culture}

The term working culture has been part of various subjects like business, sociology, history, and anthropology. To sum up the definition of organizations' working culture, it could be stated that organizational culture is composed of the values, beliefs, and traditions that are the source of motivation for its employees, and simultaneously the employees are expected to abide by those sets of beliefs and values. Out of the desirable elements that are needed by employees, one is work culture. Work culture could be described as a practice that manifests norms, shared values, and basic presumptions of all its components. (Ali, Norlinaet al, 2015). The research indicates that styles of culture and leadership are vital forces at work that influences individuals. Weber added that the leaders put the organization in the appropriate direction and set the organization's tone. Strong organizational cultures are a good source of motivation for the employees.

- Culture strengthens organizational vision and values. 
- Strong cultural organizations are a good place to work for people. Organizations take different steps in building a quality culture.

\section{Motivation}

The key to success is motivation. Life success is determined by elevating or maximizing positive and productive intentions, while minimizing counterproductive and destructive motivations. Motivation is a driving force that stimulates an individual to initiate and sustain productive behavior in an organization in a persistent manner. It is a desire that fuels an individual (Ali, Norlina et al, 2015). This study will focus on the leadership styles that best fit dynamic and complex organizations' employees to keep them motivated consistently.

\section{Hypotheses Development}

H1: Rational-legal leadership style is positively correlated with employees' motivation

H2: Traditional leadership style is negatively correlated with employee's motivation

H3: Charismatic leadership style is positively correlated with employee's motivation

H4: Rational legal leadership style is positively correlated with the working culture of organization culture

H5: Traditional leadership style is positively correlated with working culture

H6: Charismatic leadership style is negatively correlated with working culture

\section{Theoretical framework}

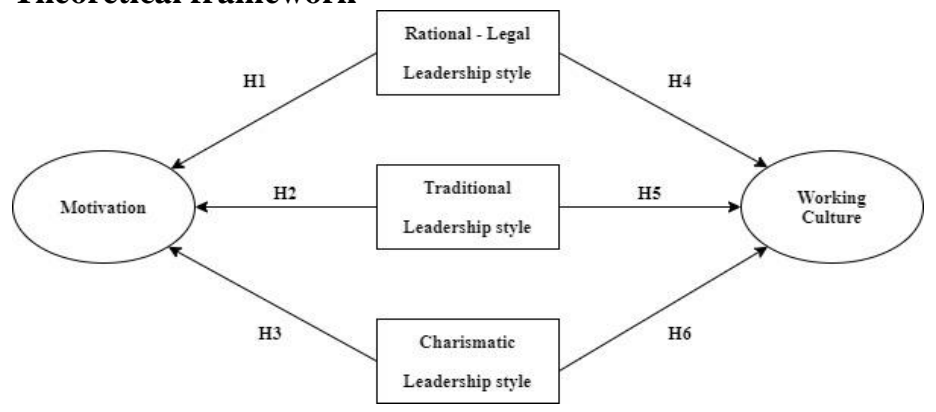

Figure 1: Theoretical framework

\section{Methodology}

This study used quantitative data collection methods. The research work used a questionnaire for gathering accurate and efficient information. This research surveys 230 respondents working in the banking sector and organizations. The questionnaires used 30 items scale with close-ended questions. We applied different statistical techniques such as frequency distribution, regression analysis, reliability analysis, and correlation to analyze the respondent's data. Data collection format was designed by dividing the questionnaire into a few parts to create interest and concentration among the respondents. A questionnaire has consisted of three sections; section A is leadership style, section B is working cultures, and section $\mathrm{C}$ is related to motivation.

\section{Population and Sample Technique}

All middle-level employees working in the government banking sector and private organizations are used as the population for this study. This study used a simple random strategy and collect data from bank employees and private organization employees. In an organization, we used a quantitative method and used a Likert scale for our questionnaires. I'll discuss further detail in the data collection section.

\section{Sample size and Data collection}

This study wants to examine the effect of leadership styles on working culture and motivation. We collected data from 230 employees. Data was gathered through employees of the banking sector and organizations. We want to know the relationship between leadership styles on motivation and working culture. We used the questionnaire method for this study in the effect of leadership style on working culture and motivation between different genders, in various age groups' interests, based on their qualification and experience, etc. We collected random data only from employees of Lahore.

\section{Data Analysis}

Table 1: Descriptive Analysis

\begin{tabular}{lccc}
\hline Variables Name & Mean & S.D. & S.E. Of Mean \\
\hline Age & 1.439 & 0.497 & 0.033 \\
Education & 1.400 & 0.491 & 0.032 \\
Experience & 3.709 & 1.060 & 0.070 \\
Traditional Leadership & 3.847 & 0.957 & 0.063 \\
Rational Leadership & 3.904 & 0.759 & 0.050 \\
Charismatic Leadership & 3.861 & 0.910 & 0.060 \\
Working culture & 3.715 & 0.990 & 0.066 \\
Motivation & 3.510 & 1.003 & 0.065 \\
\hline Table 2: Reliability & Analysis & & \\
\hline Construct Name & Cronbach & Number of & Deleted \\
& Alpha & Original Items & Items \\
\hline Rational legal & 0.742 & 6 & 0 \\
Traditional & 0.757 & 6 & 0 \\
Charismatic & 0.799 & 6 & 0 \\
Working culture & 0.89 & 3 & 0 \\
Motivation & 0.893 & 3 & 0 \\
\hline
\end{tabular}

The variable (rational-legal leadership style) consists of 6 items. The Cronbach Alpha value for the variable is 0.742 , which is well above the threshold level that is 0.7 . The second variable (Transactional) consists of 6 items. The Cronbach value for the variable is 0.757 , which is well above the threshold level, which is 0.7. The variable (Charismatic) consists of 6 items. The Cronbach Alpha value for the variable is 0.799 , which is well above the threshold level that is 0.7 . The variable (working culture) consists of 3 items. The Cronbach Alpha value for the variable is 0.890, which is well above the threshold level that is 0.7 . The variable (motivation) consists of 3 items. The Cronbach Alpha value for the variable is 0.893 , which is well above the threshold level that is 0.7 .

Table 3: Correlation Analysis

\begin{tabular}{lccccc}
\hline & RL & T & C & WC & M \\
\hline Rational legal & 1 & & & & \\
Traditional & -.102 & 1 & & & \\
Charismatic & $-.328^{* *}$ & .068 & 1 & & \\
Working culture & .004 & $.218^{* *}$ & -.094 & 1 & \\
Motivation & .063 & $.438^{* *}$ & $-.113^{*}$ & $.787^{* *}$ & 1 \\
\hline
\end{tabular}

\section{Table 4: Regression Analysis}

\begin{tabular}{|c|c|c|c|c|c|c|}
\hline \multicolumn{2}{|c|}{ Hypothesis } & Beta & S.E. & t-value & $\begin{array}{l}\text { P-value } \\
\text { - }\end{array}$ & Decision \\
\hline RLS & EM & .180 & .093 & 1.944 & .215 & NS \\
\hline TLS & EM & .146 & .066 & 2.209 & .271 & NS \\
\hline CLS & $\mathrm{EM}$ & .902 & .037 & 24.605 & 0.001 & S \\
\hline RLS & WC & .680 & .040 & 17.063 & .342 & NS \\
\hline TLS & $\rightarrow \mathrm{WC}$ & .621 & .052 & 12.041 & .237 & NS \\
\hline CLS & $\rightarrow$ VC & .798 & .046 & 17.246 & 0.004 & $\mathrm{~S}$ \\
\hline
\end{tabular}
beta-coefficients along with t-statistics as well as the S.E. value, and its significance level. 
The results of this study supported by $\mathrm{H} 1$ and $\mathrm{H} 2$ show a charismatic leadership style has a significant impact on organizational culture and motivation as high as $48 \%$. This study's results are consistent with previous studies (Shamir et al., 1993; Choi, 2006; Lee et al., 2015). Some possible explanations may include that employees often observe their leaders ' deeds and have good interaction with their leaders. Their leaders discuss specific organizational strategies and expectations with employees and describe the problems that should be observed to employees and demonstrate to the employees the matters that should be observed and noted in the workplace that slowly form the company's characteristics and are recognized by the employees. The results of this study lead conclusion that establishing and maintaining the organizational working culture depends on the degree to which the employees understand the norms of the leaders and the perceived relationship with them. Thus, this type of leadership will encourage on-the-job frontline employees in communicating the organizational environment they expect and want.

\section{Conclusion}

This study aimed to explore leadership styles and their influence on the working culture and motivation of workers. In this analysis, a quantitative approach has been used. The result of the data gathering indicates that leadership has a more significant positive effect on employee motivation and work culture. Employees feel empowered and confident in doing their job and making different decisions. Employees of each organization need a great leader to get direction to achieve the goal of the organization. In this study, three leadership styles, i.e., traditional, rational-legal, charismatic styles, are used. The findings of the survey reveal that the charismatic style of leadership is more influential. Charismatic leadership style in Pakistan is strongly linked to employee motivation within an organizational context. Charismatic leaders are building successful teams. Charismatic le aders are inspiring and assisting employees in accomplishing org anizational goals and achievements.

\section{Discussion}

The initial hypothesis in this study has a positive relationship between rational-legal leadership style and motivation. This finding is supported by similar studies demonstrating a rationallegal leadership style as important factors in terms of employee motivation but rejects these hypotheses (Bass 1985; Bass, \& Avolio, 1994; Jandaghi, ZareiMatin \& Farjami, 2009). In the second hypothesis, this study has a negative relationship between traditional leadership style and motivation of employees and this finding is rejected, supported by similar studies that demonstrated classic leadership style as important factors in terms of employee motivation (Naile, \& Selesho, 2014).

In third hypothesis this study have a positive relationship between charismatic leadership style and employees motivation and this finding supported by similar studies which have shown charismatic leadership style to be important factors in terms of employee motivation is accepted (Shamir et al., 1993; Choi, 2006; Lee et al., 2015). This study's fourth hypothesis has a positive relationship between the rational-legal style of leadership and the working culture. These findings were rejected, supported by similar studies demonstrating a rational-legal leadership style as important factors in organizational culture working culture (Health Policy and Management Department, Chung Shan Medical University; Taiwan, 2011).

In the fifth hypothesis, this study has a positive relationship between traditional leadership style and working culture, and this hypothesis is rejected This finding was consistent with previous studies (Lee, 1971; Hrebiniak, 1974; Angle \& Perry, 1981; Mathieu and Zajac, 1990; Alkahtani, Abu-Jarad, Sulaiman, \& Nikbin, 2011). This study has a negative relationship between charismatic leadership style and working culture in the sixth hypothesis, and these hypotheses are accepted. This finding supports previous research studies (Becker, 1960; Angle \& Perry, 1983; Alkahtani, Abu-Jarad, Sulaiman, \& Nikbin, 2011).

\section{Limitation and future research opportunities}

Effect of leadership style on motivation and working culture, the primary problem incurred was to collect data from leaders of organizations. It was challenging to collect data from CEOs. As the Responses are collected from 17 leaders only, and results were difficult to generalize. Questionnaires were gathered from banks of the private sector and organizations of government sector only situated in Lahore. So, when research is conducted in other cities, results may vary. The results obtained from the research indicated that charismatic leadership is most effective in employees' motivation and hence has a positive effect on the working culture of the organization. $\mathrm{N}=$ but it was unable to measure the job performance resulting from highly motivated employees.

\section{Implications for Manager and Firms}

The utility of research is for managers, employees, and the overall organization. This research may help leaders to adopt the best leadership style according to circumstances. This will guide leaders on how to learn the psychology of employees and motivate them according to their interests. In a nutshell, a firm's profitability can be enhanced when there is an appropriate leadership style and working culture and motivated employees are the most asset of an organization.

\section{References}

Alfino, S., \& Roberts, D. L. (2020). Code word usage in the online ivory trade across four European Union member States. Oryx, 54(4), 494-498.

Ali, N. M., Jangga, R., Ismail, M., Kamal, S. N. I. M., \& Ali, M. N. (2015). Influence of leadership styles in creating quality work culture. Procedia Economics and Finance, 31, 161-169.

Alkahtani, A. H., Abu-Jarad, I., Sulaiman, M., \& Nikbin, D. (2011). The impact of personality and leadership styles on leading change capability of Malaysian managers. Australian Journal of Business and Management Research, 1(2), 70.

Angle, H. L., \& Perry, J. L. (1981). An empirical assessment of organizational commitment and organizational effectiveness. Administrative Science Quarterly, 1-14.

Angle, H. L., \& Perry, J. L. (1983). Organizational commitment: Individual and organizational influences. Work and Occupations, 10(2), 123-146.

Bass, B. M. (1985). Leadership and performance beyond expectations. Collier Macmillan. 
Bass, B. M., \& Avolio, B. J. (1994). Transformational leadership and organizational culture. The International Journal of Public Administration, 17(3-4), 541-554.

Becker, H. S. (1960). Notes on the concept of commitment. American journal of Sociology, 66(1), 32-40.

Bono, J. E., \& Judge, T. A. (2004). Personality and transformational and transactional leadership: a metaanalysis. Journal of Applied Psychology, 89(5), 901.

Choi, B. C., \& Pak, A. W. (2006). Multidisciplinary, interdisciplinarity and transdisciplinary in health research, services, education and policy: 1. Definitions, objectives, and evidence of effectiveness. Clinical and Investigative Medicine, 29(6), 351.

Fleener, M. J., \& Reeder, S. (2006). Teaching Etcetera. A different 3Rs for Education: Reason, Relationality, Rhythm, 194-214.

Hrebiniak, L. G. (1974). Effects of job level and participation on employee attitudes and perceptions of influence. Academy of Management Journal, 17(4), 649-662.

Jandaghi, G., Matin, H. Z., \& Farjami, A. (2009). Comparing transformational leadership in successful and unsuccessful companies. African Journal of Business Management, 3(7), 272.

Lee, B., \& Richards, F. M. (1971). The interpretation of protein structures: estimation of static accessibility. Journal of Molecular Biology, 55(3), 379-IN4.

Lee, R., Wong, T. Y., \& Sabanayagam, C. (2015). Epidemiology of diabetic retinopathy, diabetic macular edema and related vision loss. Eye and Vision, 2(1), 1-25.
Li, C., Zhao, H., \& Begley, T. M. (2015). Transformational leadership dimensions and employee creativity in China: A cross-level analysis. Journal of Business Research, 68(6), 11491156.

Mathieu, J. E., \& Zajac, D. M. (1990). A review and meta-analysis of the antecedents, correlates, and consequences of organizational commitment. Psychological Bulletin, 108(2), 171.

Naile, I., \& Selesho, J. M. (2014). The role of leadership in employee motivation. Mediterranean Journal of Social Sciences, 5(3), 175.

Nanjundeswaraswamy, T. S., \& Swamy, D. R. (2014). Leadership styles. Advances in Management, 7(2), 57.

Rahbi, D. A., Khalid, K., \& Khan, M. (2017). The effects of leadership styles on team motivation. Academy of Strategic Management Journal, 16(3).

Shamir, B., House, R. J., \& Arthur, M. B. (1993). The motivational effects of charismatic leadership: A self-concept-based theory. Organization science, 4(4), 577-594.

Weber, M. (1947). The theory of economic and social organization. Trans. AM Henderson and Talcott Parsons. New York: Oxford University Press.

Weber, M. (1968). On charisma and institution building (Vol. 322). University of Chicago Press.

Weber, M., \& Minerva. (1974). Max Weber on universities: The power of the state and the dignity of the academic calling in Imperial Germany. University of Chicago Press. 